\title{
Thinking about teaching method innovation promotion with information technology
}

\author{
Yu Liü, a \\ ${ }^{1}$ Jilin Agricultural University, Changchun City, Jilin province, China \\ a37373021@qq.com
}

Keywords: Information technology, Teaching methods, Innovation and thinking

\begin{abstract}
The traditional teaching method, and the communication between students and teachers of the media is simple, students study hard, also appears dull teaching activities. Multimedia teaching make full use of audio and video signals to make teaching more fun, the students in the teaching has the feeling of immersive, multiple stimulus have learning excitement, such can enhance their learning interest and enthusiasm, and greatly improved the teaching quality. So how information technology is summarized in the primary problems should be paid attention to in teaching, so that to promote the information of teaching reform, improve the teaching effect of purpose.
\end{abstract}

\section{Introduction}

With an updated information and technology, modern information technology application in elementary school science teaching is the needs of the development of times. It helps to better fulfill the goals of the elementary school mathematics course, achieve the goal of cultivating students' innovative spirit and practical ability [1]. The rapid development of modern science and technology, and constantly impact and promote the reform of the education, science and technology and the development of education technology in the 21st century, to make people realize the modern education technology application and promotion, in the modern personnel training plays a more and more important role [1]. Education means and methods of updating is a key project of teaching reform. And the application of multimedia breaks through the traditional education means and methods, the teaching activities present a whole new look.

Traditional teaching methods there are many places out of date, and the communication between students and teachers of the media is simple, students study hard, also appears dull teaching activities. Now electronic teaching has broken the traditional teaching model, it adopts the multimedia audio equipment to audio, video, projector, DVD player, teaching software and even a variety of teaching media, such as computers, to focus on one, by teachers according to the requirements of different class type, the flexible use of related media in teaching practice [1]. Multimedia teaching make full use of audio and video signals to make teaching more fun, the students in the teaching has the feeling of immersive, multiple stimulus have learning excitement, such can enhance their learning interest and enthusiasm, and greatly improved the teaching quality. So how to live the better and using of media for teaching to achieve the requirement of the new curriculum and to make the innovation used is the key task for the teaching innovation.

\section{The promoting role of information technology in teaching}

In traditional teaching, not only there is way to learn a single, the lack of resources, single teaching mode, and so on and so forth. And some teachers in consciously or unconsciously plays a teaching activity leaders, knowledge, the narrator, the role of information transmission [2]. But now, our era is the era of information technology, the rapid development of information technology to education career has brought the profound influence, make the traditional classroom teaching mode has received the unprecedented challenge. Of course, this also with people look forward to the ideal education, it can be more convenient, easy and free learning [2]. By using modern education technology to teaching in improving teaching quality, improve the learning efficiency, expand the scale of education and so on various aspects has incomparable advantage over the traditional teaching. 
In the discipline teaching, therefore, the information technology teaching means is the development direction of modern education reform, information technology education task and goal is to create conditions, actively use information technology to carry out all kinds of disciplines teaching, cultivating students' good information literacy, pay attention to cultivate students' innovation spirit and practice ability, and the information technology as a means of cooperative learning and lifelong learning.

To explore the use of information technology stimulates students' interest. The use of multimedia can greatly enhance the value of education as the important resources of teachers. In literature class, for example, we can use video, VCD and other audio-visual media will teachers from repeated teaching link, so that teachers can be a valuable distribution of time, effort, and wisdom to problem solving and innovative research [2]. Multimedia can reduce the students' passive waiting, increased the opportunity to learn, and can convert passive learning into active learning. Compared to other courses such as moral character and nature no experiment, so few opportunities for the students directly involved in the teaching process, students only class and just a handful of students, the majority of students are accustomed to passively listening to the teacher in class teaching, students' main body role to play.

Use technology to improve teaching effect. Use of multimedia courseware teaching, can optimize the classroom teaching process, strengthen the effect of classroom teaching. For example, I learned in several class "flat line four side face product" section, if taught master single pure language describe flat line four side area with the rectangular area is same, calculated the $\mathrm{S}$ flat bottom $\mathrm{X}=$ high, students may ask why, but also for this formula can only by rote, like this cannot achieve good teaching effect [3]. And to use multimedia courseware to let students to observe the parallelogram through segmentation, the whole process of the fill animation effects will eventually become a rectangle.

Use arouses the curiosity of students' learning interest technology. Often in the teaching, the content of the new lesson we learned the same lesson knowledge has no connection, this will give us the import new lesson the link brings inconvenience [3]. Such as in the calculation teaching, due to the content of every class are some operational problems, and that the link between various operational problems are not big, so that we can't use a question to draw out the next question. Then we can use new knowledge of show good multimedia courseware to students, let them by observing the courseware to discover new knowledge, new content, so as to lead to a new lesson.

Using the technology for abstract knowledge specific and visualization. A lesson was good or bad, success or not, on a very important aspect is to see any outstanding teaching important points and break through the teaching difficulties. Only with the help of the traditional teaching means and many subjects are difficult to achieve a goal [4]. In science teaching, for example, many life phenomena often taught as an abstract concept, students' learning lack of perceptual knowledge, so dull, cause learning difficulties for some knowledge, but biological phenomena of life are important and difficult. Then we can use multimedia courseware to break through the traditional teaching can't solve the problem, make the abstract concept of visualization, make dull content vivid, stimulate students interest and imagination, not only reduce the difficulty of learning, and broke through the heavy and difficult.

Stimulate students' learning motivation and enhance the students' learning initiative and enthusiasm. In the elementary school mathematics teaching, to change students change from passive acceptance learning seeks to explore the learning, the teacher must practice the teaching democracy, equality, democracy, harmonious and relaxed classroom atmosphere, to give students more autonomy, make each student dares to ask, dare to dare to show, to maximize the activate students potential exploration desire, stimulate their exploring interest. , therefore, in mathematics teaching, teachers must be good at using the modern information technology means, creating vivid and specific learning situation, choose student can receive the actual examples to lead class, created for students to discover, explore learning mood, stimulate the learning enthusiasm of the students, arouse the students' participation desire, and trigger the students' curiosity and interest of students, explore independently, actively participate in learning activities, to build confidence, causing students' 
positive thinking [4]. This achieved the purpose of teaching, and inspired the students' learning motivation, change passive to active learning.

\section{The education of information technology in the teaching of science innovation}

In July 2010, promulgated by the China national medium and long-term education reform and development plan outline (2010-2020), "information technology has a revolutionary influence on education development, must be attached great importance to " [5]. Here "revolutionary", should be understood as a disruptive change, although have a little change as the emergence of the text to record information, revolutionized the "word of mouth" type of knowledge transfer mode, with multimedia technology, network technology and the CAI courseware for the core of modern education technology and the advent of development, the revolution of mathematics teaching means. This is not merely a kind of challenges and opportunities, but also a kind of innovation.

Education modernizations drive information. Information technology as a means to teacher's teaching way has a lot of influence, in the early stages of the information technology into the classroom, the information technology application in the teaching process is not very ideal, the teacher passively using information technology in the classroom teaching, the teachers' use of information technology equipment is a number of requirements, each teacher in the school year must use a certain amount of time [5]. But development up to now, we can see that the teachers in the school is to use information technology equipment, and many teachers will have information technology equipment involved in the daily classroom teaching, in the absence of information technology to support teachers, it is difficult to teach well.

Change in the way of learning. Information technology into daily life, we all deal with information technology tools, we at the same time of using these tools, these tools are also quietly to reverse the way to learn we continue in one hundred [6]. In our daily learning process, for example, when encountered some words don't know, we have to turn to the dictionary, but now many people's first reaction is to get to the Internet, go online to find relevant explanation, also exploring some things did not come in contact with before, we also often is to first go to the Internet search related content, in order to have a preliminary understanding of the thing, which is now often referred to a way of learning "is learning".

Change in the way of teaching interaction. In the traditional teaching process, teachers and students interaction often occurs in school class or classes below the opposite interaction, this interaction is constant in time for the teachers and students, this leads to the teachers and students interaction does not become effective interaction [4]. And modern, with the development of information technology, many teachers and students of communication is the use of such as QQ, MSN, blog, micro blog tool or means of information technology, to remain with the help of these tools and means, and students and teachers can not only realize real-time or asynchronous interaction, at the same time also can realize between teachers and students, between the one-to-many and many-to-many interactions, which greatly improve the efficiency of teaching interaction.

Changing and education teaching organization form. Under the influence of information technology, the modern classroom teaching organization form has been changed, the information technology as a new media into the classroom teaching, the teachers in the teaching process with multimedia tools to implement and the large amount of information, at the same time the use of information communication tools in the classroom to achieve the multidirectional transmit information between teachers and students, these changes brought by information technology with deep into every classroom [5].

At the same time, under the influence of information technology, teacher's teaching, there has been a shift in the traditional teaching, more is carried out in the form of school-based teaching and research, and modern research under the auxiliary of the information technology, great changes have taken place in the use of information technology and resources, such as the project site, resource, and the commonly used communication tools, such as the discipline of teachers to be able to ignore the actual distance, communicate with teachers in thousands of miles away to distance teaching and research, which will be beneficial to teachers to achieve broader aspects of the teaching interaction. 
Change of concept of classroom teaching. Information technology in the present classroom teaching and classroom teaching in the education of ideal combination of well originally in the absence of class teaching, we adopt the kind of teaching, the school teaching the advantage of it to students as the center, the teacher will teach what students want to learn, teachers can targeted personalized teaching mode guides the student to study [6]. The disadvantages of inefficiency lies in its teaching process, students' lack of collective activity in the process of learning, lack of peer interaction, the cultivation of the students lack the sense of team. Class teaching with high efficiency, at the same time, can learn from each other, between students and students but the teacher centered not conducive to the development of personalized student. Under the influence of the technology, that can make school education and the integration of class education. Technology into education for class teaching, it is not only involves the means of change, it involves all aspects of change, involves the education idea, involves the structure of courses, and even involved in the goal of education.

Modern information technology to change the teaching effect [6]. 1) Teaching resources sharing. In the process of modern teaching, teaching content and information not only exist in a variety of forms, and a lot of content and materials after the digital storage, but also for the majority of teachers and students information via the digital library, information network sharing provides a convenient. 2) Open teaching form. Because of modern information technology is combined with computer through the network system, multimedia technology, advanced design idea and way of human-computer interaction into consideration, it will effectively cover the school each unit of the computer network, the entire information is open, through all the campus net classroom, laboratory and office and student dormitory together. 3) Personalized teaching way. With multimedia technology and network communication technology as the core of information technology for the modern network education provides an interactive learning environment. In this kind of learning environment, students can learn at their own foundation, the interest to choose what they want to learn the contents of the, can choose to suit oneself level of practice; also can choose different teaching models to study. 4) Teaching environment virtualization. Teaching environment virtualization means teaching activities can largely out of the limit of physical space and time; this is the important characteristics of network education. Campus network has been set up in many schools, if can fully develop network virtual education function, can truly virtual education and education, the school education and school education, it is the development direction of future information technology school.

Information technology is helpful to improve students' ability of autonomous learning. Long-term since, our country's education is not only a teacher single way of teaching, students learning style is single [7]. Teachers are not granted to fish, but teaching them to fish. At present, the development of social change speed, all kinds of information with each passing day, students need to have a strong ability to adapt, single teaching to cultivate students of the limitations of thinking, this will be conducive to the growth and development of students. Change this need with the help of information technology means, cultivate students' autonomous, inquiry and cooperative learning ability, make students more learning.

Information technology will help students to carry out exploratory learning. Dynamic development of information technology itself, bring broad space of inquiry learning [1]. Information technology application in the production, every aspect of life, will be applied to the inquiry learning, the selected topic, practical instructive. Network resources are rich, which is beneficial to students in the vast sea "' resources exploration, discovery.

Information technology can help students to carry out the cooperative learning. Collaborative learning is beneficial to promote the development of students' cognitive ability, help students cooperation consciousness and skills, the cultivation of ability, the sense of responsibility and quality. Information technology for collaborative learning provides a good technical basis and support environment, students can through the competition, synergy patterns such as cooperation and communication [7]. Doing business training clothing business activities, for example, we divided the students into four groups, respectively responsible for product introduction, airport pick up, hotel and the contract is signed, every link to let the students use their spare time, make full use of information 
resources, collecting relevant data, finally linked together, to complete the training topic, this cooperation has received the good effect.

Information technology information technology helps the foundation of the higher education and lifelong. Due to the basic knowledge with relative stability, the importance and conciseness, in the face of the world of "knowledge explosion", the university campus of finite time is only a strengthening basic education [7]. At the same time, efficiency of information technology, let the students have the opportunity to understand the subject development frontier, help to develop students' vision, improve the ability of knowledge, so that in the future through lifelong education constantly improve their own knowledge structure. The development of information technology helps higher education foundation and the realization of lifelong. The ultimate goal of higher education in the future society will change, no longer just for the sake of a graduate diploma, but to the lifelong education. Institutions of higher learning are to meet the needs of different social strata people, provide all kinds of different levels of rich and colorful education courses online.

\section{Summary}

At present, based on information technology of the new education pattern is getting closer and closer to people, information technology to promote education is increasingly apparent, realize the education information, information promoting education modernization, is the era have entrusted to education workers the glorious and arduous historical mission. Education field should actively cope with the effects of information technology, each education workers should be devoted to the modern information technology to promote the tide of reform and development of education, the real from the management level and at the level of education content to accept and absorb information technology and its products, gripped education opportunities for development, research and information technology and subject teaching integration, out of a drive education modernization by the information, information technology affects school leapfrog development of the road to success, to make due contributions to the development of education modernization in China.

\section{Acknowledgement}

This project, Research on the Existence of Quasi-periodic Solutions to Partial Differential Equations with Given Frequencies, is supported by Foundation for Scientific Research Projects of the Education Department of Jilin Province (Project No.: 2016166). Project Principal: Jing Chang.

\section{References}

[1] D.R. Fu, multimedia technology and its application education, Beijing: Higher education press, 2003, pp. 42-45.

[2] Y.B. Liu, multimedia technology and application, Beijing: Tsinghua university press, 2004, pp. 54-58.

[3] Q.T. Zhong and Zh.T. Zhu, Information technology in education, Shanghai: East China normal university press, 2012, pp.32-37.

[4] W.R. Huang, Information technology and English teaching, Jilin Northeast normal university press, 2013, pp. 21-25.

[5] R.Y. Li, The research content and development trend of modern education technology, Beijing normal university foreign language teaching, 2014, vol. 1, pp. 12-15.

[6] S.T. Qin, Information technology with the influence of modern education, Audio-visual education research, 2010, vol.6, pp.32-37.

[7] K.S. Yang, The design principles of constructivism learning environment, Beijing normal university press, 2015, vol. 7, pp. 32-35. 